\title{
PERANAN SISTEM PENGENDALIAN INTERNAL ATAS PENJUALAN UNTUK MENINGKATKAN EFEKTIVITAS PENERIMAAN KAS PADA (PT. SINAR SOSRO KANTOR PENJUALAN BOGOR)
}

\author{
THE ROLE OF THE INTERNAL CONTROL SYSTEM FOR SALES \\ TO IMPROVE THE EFFECTIVENESS OF CASH ADMISSION \\ (PT. SINAR SOSRO BOGOR SALES OFFICE)
}

\author{
Vini Virgini Agustiani, Indupurnahayu, Hurriyaturrohman \\ Fakultas Ekonomi dan Bisnis Universitas Ibn Khaldun Bogor, Indonesia \\ indupurnahayu@yahoo.co.id
}

\begin{abstract}
Internal control system is very important to leaders corporation in order to monitor the policies which has on set and giving confidence to him that the purpose of the company would be could be achieved. The type research used in this study descriptins and research method used is qualitative, said qualitative because there is data that is not nominated by using the numbers, but presented in the from of description, explanations, and discussion of theory.The research result showed that PT.Sinar Sosro Sales Office in Bogor has implemented the system internal control the sales and acceptance of cash that good and adequate support association of operational activities company. This can be seen from internal control consisting of several components internal control supported with the separation of the functions and clear authority, as well as the documents adequate in its procedures acceptance of cash from the sale of cash.
\end{abstract}

Keywords : Internal Control System, Sales, and Cash Receipts

\begin{abstract}
ABSTRAK
Sistem pengendalian internal merupakan hal yang sangat penting bagi pimpinan perusahaan dalam rangka memantau kebijakan-kebijakan yang telah ditetapkan dan memberikan keyakinan kepadanya bahwa tujuan perusahaan akan dapat dicapai. Jenis penelitian yang digunakan dalam penelitian ini deskripsi serta metode penelitian yang dipakai adalah kualitatif, dikatakan kualitatif karena terdapat data yang tidak dapat dinominalkan dengan menggunakan angka-angka, melainkan disajikan berupa keterangan, penjelasan, dan pembahasan teori. Hasil penelitian ini menunjukan bahwa PT.Sinar Sosro Kantor Penjualan Bogor telah menerapkan sistem pengendalian internal atas penjualan dan penerimaan kas yang baik dan memadai dalam menunjang kegiatan operasional perusahaan. Hal ini dapat terlihat dari pengendalian internal yang terdiri dari beberapa komponen pengendalian yang didukung dengan adanya pemisah fungsi dan wewenang yang jelas, serta dokumen-dokumen yang memadai dalam prosedur penerimaan kas dari penjualan tunai.
\end{abstract}

Kata Kunci : Sistem Pengendalian Internal, Penjualan, dan Penerimaan Kas

\section{PENDAHULUAN}

Bagi setiap perusahaan baik yang besar maupun kecil, yang berorentasi profit maupun yang non profit akan mempunyai perhatian yang besar terhadap keuangan dari perusahaan tersebut. Keberhasilan, maupun kegagalan dalam usahanya hampir sebagian dipengaruhi ataupun ditentukan oleh keputusan keuangan perusahaan tersebut dengan kata lain masalah yang biasa timbul dalam setiap organisasi berimplikasi terhadap bidang keuangan.

Dengan kemajuan teknologi dan komunikasi, maka sudah sepantasnya perusahaan dapat menciptakan sistem pelaporan informasi yang baik, relevan, 
tepat waktu, dapat dipercaya dan secara keseluruhan informasi tersebut bermanfaat atau berguna. Sehingga dapat digunakan sebagai dasar dalam mengambil keputusan.

Pengendalian internal dalam perusahaan dilakukan untuk mengatur dan mengkoordinasi kebijakan manajemen dalam perusahaan untuk menghindari kecurangan, penyelewengan, pemborosan dan pencurian maka manajemen harus meningkatkan kebijakan dalam pengendalian internal. Pengendalian internal sendiri memiliki pengertian suatu proses yang melibatkan manajer dalam mengatur, mengarahkan dan menerapkan suatu kebijakan didalam suatu perusahaan agar tujuan perusahaan dapat tercapai, salah satu unsur yang paling penting dalam perusahaan dagang adalah persediaan yang dijual. Persediaan merupakan barang dagangan yang dibeli kemudian disimpan untuk selanjutnya dijual kembali dalam operasi. Perusahaan senantiasa memberi perhatian yang besar dalam persediaan (irna, 2015,5).

Salah satu aktivitas perusahaan yang penting adalah penjualan dan penerimaan kas. Seperti yang kita ketahui kas terlibat dalam hampir semua transaksi perusahaan, kas dapat dengan mudah diubah menjadi asset lain, kas juga begitu penting karena perusahaan harus memperhatikan pada saat penerimaan kas dalam penjualan yang secara langsung berhubungan dengan pembelidan kasir, sistem pengendalian internal yang baik memiliki prosedurprosedur yang harus diterapkan dalam pengendalian penerimaan kas dari penjualan tunai dan kredit untuk menghindari penyimpangan yang tidak menguntungkan, sehingga rencana dan tujuan yang ingin dikehendaki dapat mudah dicapai.
Sehingga penjualan kas dilakukan pengenalan barang sesuai ukuran, jenis, model dll, dan kualitas yang baik, Oleh karena itu persediaan sangat perlu dijaga untuk kelangsungan kegiatan perusahaan yang bersangkutan, baik prosedur penerimaan, pengeluaran, dan pencatatan.

Pengendalian internal atas penjualan merupakan fungsi manajerial yang sangat penting, karena pengendalian internal atas penjualan ini banyak melibatkan investasi rupiah dan mempengaruhi efektivitas dan efisiensi kegiatan perusahaan. Dengan pengendalian internal yang memadai dapat mengurangi resiko terjadinya selisih, kehilangan, mengantisipasi kemungkinan terjadinya kecurangan dan memastikan bahwa prosedur telah dilakukan dengan baik sehingga kemudian dapat dibuatlah perbaikan (silistaryaningsih, 2013;10)

Penjualan bagi perusahaan manufaktur merupakan suatu bagian yang sangat penting, yang tidak dapat dipisahkan dalam kegiatan operasionalnya dimana tanpa adanya penjualan perusahaan akan menghadapi risiko ketidakmampuan memenuhi keinginan para langganan. Sistem pengendalian internal yang baik diperlukan agar kegiatan operasional lebih terorganisir sehingga dapat berjalan dengan efektif dan efisien.

Dalam perusahaan dagang seperti supermarket mereka telah menyediakan alat rumah tangga, bahkan bisa dibilang sangat lengkap. Sistem pengendalian internal atas penjualan yang ada diperusahaan tersebut mungkin sudah cukup baik.

Berdasarkan uraian diatas, penulis bermaksud untuk melakukan penelitian untuk mengetahui system pengendalian internal yang dijalankan oleh perusahaan tersebut, maka penulis tertarik untuk mengambil judul : "Peranan Sistem 
Pengendalian Internal Atas Penjualan Untuk Meningkatkan EFEKTIVITAS Penerimaan Kas (Pada PT. Sinar Sosro Kantor Penjualan Bogor)".

\section{Pengumpulan Data}

Metode pengumpulan data menggunakan metode kualitatif, yakni metode ini, dilakukan dengan cara melakukan pengamatan, pencatatan. Metode ini juga melibatkan peneliti untuk mempelajari proses yang terjadi secara alami, menganalisis, menafsirkan, dan melaporkan serta menarik kesimpulankesimpulan dari proses tersebut, jenis dan desain yang digunakan, yakni:

1. Wawancara

Memperoleh data dengan melakukan wawancara langsung dengan pihak yang berwenang untuk mendapatkan informasi yang relevan dengan apa yang dibahas.

2. Dokumentasi

Untuk mengumpulkan dokumendokumen dari perusahaan terkait dengan proses penjualan masalah yang dibahas, laporan keuangan perusahaan, berita acara pembayaran dan juga dokumen dokumen terkait lainnya.

\section{Metode Analisis Data}

Metode analisis data yang digunakan adalah metode analisis data kuantitatif kualitatif yaitu mengumpulkan dan menginterfrestasikan data-data yang diperoleh dan kemudian diolah kembali sehingga apat dibahas setelah gambaran tersebut diperoleh. Selanjutnya data tersebut dianalisis dan ditelaah secara umum lalu dihubungkan dan di bandingkan dengan teori yang berkaitan dengan obyek yang diteliti. Baik dari prosedur serta kebijakan yang diambil dalam menyelesaikan masalah. Dari hasil analisis ini dapat diketahui permasalahan, dan selanjutnya dicarikan penyelesaiannya, lalu kemudian didapat kesimpulan dari penelitian.

\section{Sistem}

Menurut Mulyadi (2010:5) sistem adalah sekelompok unsur yang erat berhubungan satu dengan yang lainnya, yang berfungsi bersama-sama untuk mencapai tujuan tertentu dan diciptakan untuk menangani sesuatu yang berulang kali atau rutin terjadi. Pada suatu organisasi, sistem akuntansi memegang peranan yang sangat penting dalam mengatur arus pengelolaan data akuntansi yang diperlukan oleh setiap perusahaan. Hal ini diperlukan agar dapat menghasilkan informasi yang tetap dalam bentuk yang sesuai, sehingga operasi perusahaan dapat berjalan dengan baik dalam mencapai tujuan perusahaan. Sistem akuntansi yang diterapkan oleh suatu perusahaan yang berlainan, hal ini bergantung pada kebutuhan serta luas ruang lingkup perusahaan tersebut.

\section{Prosedur}

Menurut Mulyadi (2010.5) prosedur adalah kegiatan klerikal, biasanya melibatkan beberapa orang dalam suatu departemen atau lebih, yang dibuat untuk penanganan secara seragam transaksi perusahaan yang terjadi berulang-ulang. Sedangkan menurut Baridwan (2019-30) prosedur merupakan suatu urutan-urutan pekerjaan kerani (clerical) biasanya melibatkan beberapa orang dalam suatu bagian atau lebih, disusun untuk menjamin adanya perlakuan sebagai perlakuan terhadap transaksi-transaksi perusahaan yang sedang terjadi.

Dari definisi yang telah dikemukakan tersebut bisa disimpulkan bahwa prosedur adalah suatu urutan kegiatan tertentu yang biasanya melibatkan beberapa orang dalam 
suatu departemen atau lebih yang dibuat untuk diperlakukan seragam atas transaksi perusahaan yang terjadi berulang ulang, sedangkan untuk prosedur pengendalian adalah kebijakan, kategori prosedur pengendalian antara lain harus adanya pemisahan tugas yang cukup untuk menengah salah saji bagi yang disengaja maupun yang tidak disengaja dalam pemisahan tugas seperti :

1. Pemisahan otorisasi dan pemegang aktiva yang bersangkutan.

2. Pemisahan pemegang aktiva dari akuntansi.

3. Pemisahan tanggung jawab operasional dari tanggung jawab pembukuaan.

Selain itu harus adanya otorisasi yang pantas atas transaksi dan aktivitas dengan pantas jika tidak ada, mudah terjadi kecurangan. Otoritasi dalam bentuk umum berarti bahwa manajemen menyusun kebijakan dari organisasi untuk ditaati, sedangkan otorisasi khusus dilakukan terhadap transaksi individual.

\section{Sistem Pengendalian Internal}

Arens (2011:258) pengendalian internal sebagai berikut; "pengendalian internal adalah kebijakan-kebijakan dan prosedur-prosedur yang dirancang untuk memberikan manajemen keyakinan memadai bahwa tujuan dan sasaran yang penting bagi satuan usaha dapat dicapai dan secara bersama sama membentuk struktur pengendalian internal suatu usaha".

Boynton (2011;112), pengendalian internal adalah suatu proses yang dilaksanakan oleh dewan direksi, manajemen dan personel lainnya dalam suatu entitas yang dirancang untuk menyediakan keyakinan yang memadai berkenan dengan pencapaian tujuan dalam kategori berikut ini yaitu keandalan pelaporan keuangan, kepatuhan terhadap hukum dan peraturan yang berlaku dan efektivitas dan efesiensi operasi”.

$$
\text { Sedangkan Diana }
$$

pengendalian internal adalah semua rencana organisasional, metode, dan pengukuran yang dipilih oleh suatu kegiatan usaha untuk menguntungkan harta kekayaannya, mengecek keakuratan dan keandalan data akuntansi usaha tersebut, meningkatkan efesiensi operasional, dan mendukung dipatuhinya kebijakan manajerial yang telah ditetapkan, pengendalian internal meliputi beberapa aktivitas, yaitu:

1. Perencanaan

2. Koordinasi antar berbagai bagian dalam organisasi

3. Komunikasi organisasi

4. Pengembalian keputusan

5. Memotivasi orang-orang dalam organisasi agar perilaku sesuai dengan tujuan organisasi

6. Pengendalian

7. Penilaian kerja

\section{Efektivitas}

Georgopolous dan Tannembaum (2010;11) mengemukakan bahwa "efektifitas ditinjau dari sudut pencapaian tujuan, dimana keberhasilan suatu organisasi harus mempertimbangkan bukan saja sasaran organisasi tetapi juga mekanisme mempertahankan diri dalam mengejar sasaran. Dengan kata lain.penilaian efektivitas harus berkaitan dengan masalah sasaran maupun tujuan" selanjutnya steers mengemukakan "efektifitas adalah jangkauan usaha suatu program sebagai suatu system dengan sumber daya dan saran tertentu untuk memenuhi tujuan dan sasaran tanpa melumpuhkan cara dan sumber daya itu serta tanpa memberi tekanan yang tidak wajar terhadap pelaksanaanya". 
Lebih lanjut menurut Kurniawan dalam bukunya Transformasi pelayanan public mendefinisikan efektifitas, sebagai berikut "efektifitas adalah kemampuan melaksanakan tugas, fungsi (operasi kegiatan program atau misi) dari pada suatu organisasi atau sejenis yang tidak adanya tekanan atau ketegangan diantara pelaksanaanya" (Kurniawan, 2011:109) dari beberapa pendapat diatas mengenai efektifitas, dapat disimpulkan bahwa efektifitas adalah suatu ukuran yang menyertakan seberapa jauh target (kuantitas, kualitas dan waktu), yang telah dicapai oleh manajemen, yang mana target tersebut sudah ditentukan terlebih dahulu. Hal ini sesuai pendapat yang dikemukakan oleh hidayat yang menjelaskan bahwa "efektifitas adalah suatu ukuran yang menyatakan seberapa jauh target (kuantitas, kualitas dan waktu) telah tercapai. Dimana makin besar presentase targert yang dicapai, makin tinggi efektifitasnya“.

\section{Pengertian Penjualan}

Aktivitas utama perusahaan yang tidak kalah pentingnya adalah penjualan yang merupakan salah satu fungsi dari cukup penting dalam suatu perusahaan, karena penjualan merupakan sumber utama pendapatan atau penerimaan perusahaan. Dalam hal ini penulis lebih menekankan pada sistem penjualan.

Menurut Basusuastha (2010:8) dalam Yos (2009:23) definisi penjualan adalah ilmu dan seni mempengaruhi pribadi yang dilakukan oleh penjual untuk mengajak orang lain agar bersedia membeli barang atau jasa yang ditawarkan.

Sedangkan menurut Azar Susanto aktifitas (2004:170) penjualan adalah sebagai berikut:

1. Aktifitas adalah sumber pendapatan perusahaan. Kurang dikelolanya aktifitas penjualan dengan baik, secara langsung akan merugikan perusahaan karena selain sasaran penjualan tidak tercapai, juga pendapatan akan berkurang.

2. Pendapatan dan hasil penjualan merupakan hasil pembayaran perusahaan maka perlu diamankan.

3. Akibat adanya penjualan akan merubah posisi harta yang menyangkut :
a. Timbulnya piutang kalau penjualan secara kredit masuknya uang kontan kalau tunai
b. Kuantitas barang yang akan berkurang dari gudang karena penjualan yang terjadi.

Dari definisi di atas, dapat diambil kesimpulan bahwa penjualan adalah suatu pemindahan hak kepemilikan atau barang atau jasa dari pihak penjual kepada pihak pembeli yang disertai dengan penyerahan imbalan dari pihak yang menerima barang dan jasa timbal balik atas jasa penyerahan tersebut.

\section{Kas}

Kas adalah sebagai uang beserta pos pos lain yang dalam jangka waktu dekat dapat diuangkan sehingga dipakai sebagai alat untuk membayar kebutuhan finansialnya atau suatu bentuk kekayaan perusahaan yang paling liquid". (Manullang, (2011:24), pengertian kas lainnya adalah : "kas adalah alat pembayaran yang siap dan bebas dipergunakan untuk membiayai kegiatan umum perusahaan”. (Agoes,2012:167).

Menurut Harahap (2011;258) kas adalah uang dan surat berharga lainnya yang dapat diuangkan setiap saat serta surat berharga lainnya yang sangat lancar yang memenuhi syarat sebagai berikut :

1. Setiap saat dapat ditukar menjadi kas

2. Tanggal jatuh temponya sangat dekat 
3. Kecil resiko perubahan nilai yang disebabkan perubahan tingkat harga

\section{Penerimaan Kas}

Transaksi penerimaan kas adalah transaksi keuangan yang menyebabkan Asset perusahaan berupa kas atau setara kas bertambah. Transaksi penerimaan kas dicatat ke sistem komputer pada formulir elektronik penerimaan kas dan dibukukan oleh sistem komputer ke jurnal penerimaan Kas sesuai dengan methode yang ditetapkan. Setiap penerimaan kas selain nilai nominal juga harus menunjukan tanggal terjadinya transaksi, tanggal efektif, dokumen referensi, buyer, sumber penerimaan kas, transaksi yang terkait, keterangan ringkas, dll. Penambahan kas yang diperoleh dari pendapatan bunga, selisih kurs lainnya dicatat pada jurnal memorial.

\section{Kerangka Pemikiran}

Peranan sistem pengendalian internal atas penjualan untuk meningkatkan efektifitas penerimaan kas sangatlah penting, mengingat penjualan merupakan pendapatan yang real bagi setiap perusahaan. Meningkatnya efektivitas penjualan sangat diperlukan oleh setiap perusahaan, agar perusahaan tersebut dapat berkembang dalam menghadapi globalisasi.

Oleh karena itu, peranan sistem pengendalian internal atas penjualan sangatlah erat hubungannya dengan penerimaan kas.

\section{Paradigma Penelitian}

Berdasarkan kerangka pemikiran yang telah dikemukakan, maka peranan system pengendalian internal atas penjualan untuk meningkatkan efektivitas penerimaan kas akan digambarkan dalam paradigma penelitian sebagai berikut :

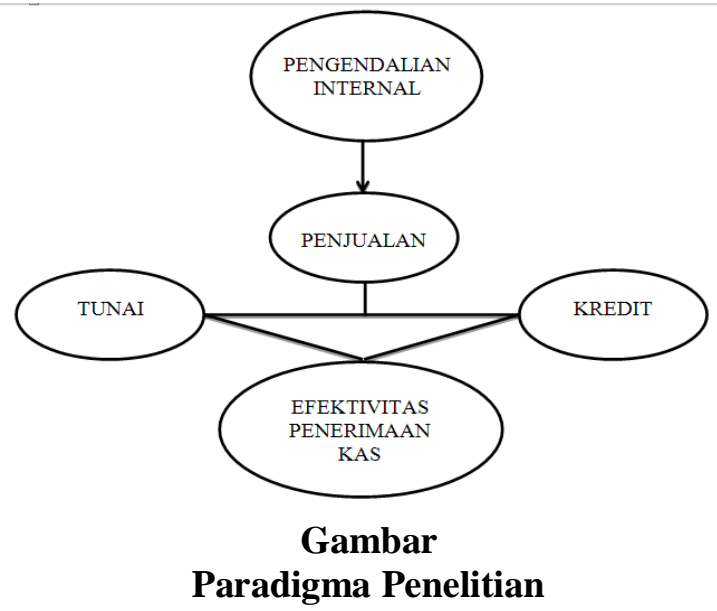

\section{HASIL DAN PEMBAHASAN}

Sistem dan Prosedur Atas Penjualan yang Diterapkan Di PT. Sinar Sosro

\section{Sistem dan Prosedur Penjualan Tunai}

1. Sistem Penjualan Tunai

Sistem penjualan tunai merupakan sistem yang diberlakukan perusahaan dalam menjual barang dengan cara mewajibkan pembeli untuk melakukan pembayaran harga terlebih dahulu sebelum barang diserahkan pada pembeli, kemudian transaksi penjualan dicatat.

2. Prosedur, bagian, dan dokumen Penjualan Tunai

Prosedur yang membentuk sistem dalam sistem penjualan tunaiadalah sebagai berikut:

a. Prosedur Penjualan

Dalam prosedur ini, penjualan dilakukan oleh bagian penjualan yaitu salesman. Salesman ini bertanggung jawab menawarkan produk dan mendistribusikan ke konsumen. Jika terjadi transaksi maka salesman akan membuka faktur penjualan.faktur ini ditanda tangani oleh salesman dan pelanggan. Faktur ini terdapat 4 rangkap,dimana lembar ke 1 diberikan kepada pelanggan, lembarke 2 diberikan kepada 
administrasi piutang, lembar ke 3 diberikan kepada administrasi penjualan dan lembar ke 4 di arsip oleh salesman.

b. Prosedur Penerimaan Kas

Salesman akan membuat bukti penerimaan kas yang akan diperiksa oleh bagian kasir dan disetujui oleh supervisor admin. Pembayaran dari konsumen dapat berupa uang tunai atau melalui transfer dari bank. Bukti ini terdiri dari 2 rangkap. Lembar 1 disimpan dibagian kasir sebagai bukti penerimaan yang sah atas penjualan tunai, dan lembar ke 2 untuk salesman.uang tersebut akan disetorkan ke security call setiap harinya.bukti penerimaan kas yang ada dikasir setiap bulannya dikirim ke accounting pusat.

c. Bagian yang terkait dalam penjualan tunai

1) Bagian penjualan

Bagian penjualan bertanggung jawab melayani kebutuhan barang pelanggan. Bag. Penjualan mengisi Dokumen order penjualan (SO) untuk memungkinkan bag. Gudang dan bag. Pengiriman untuk melaksanakan penyerahan barang ke pelanggan.

2) Bagian gudang

Setelah disetujui, bag. Penjualan mengirimkan tembusan (SO) ke bagian gudang (biasa disebut order pengiriman) untuk mengeluarkan barang dari gudang. Selanjutnya bag. Gudang menyerahkan barang sesuai yang tertera pada Order Pengiriman ke bag.
Pengiriman untuk segera dikirimkan.

3) Bagian salesman

Salesman menawarkan atau menjual barang kepada konsumen, dan melakukan pendekatan dengan konsumen karena rasa simpatik konsumen merupakan salah satu kunci tercapainya keberhasilan penjualan ini.

4) Bagian staf administrasi

Bahwa staf administrasi bentuk kerja sama antar dua orang atau lebih untuk mencapai tujuan bersama,staff administrasi berfokusuntuk rekap data, menjawab telpon masuk, pembuatan surat, melakukan penjadwalan, front office, dan memiliki keahlian lainnya.

5) Bagian kasir

Menjalankan proses penjualan dan pembayaran, melakukan pencatatan atas semua transaksi, membantu pelanggan dalam memberikan informasi mengenai suatu produk, melakukan proses transaksi, melakukan pengecekan atas jumlah barang pada saat penerimaan barang, melakukan pengecekan atas stock bulanan.

d. Dokumen yang digunakan dalam penjualan tunai

1) RRK (Rencana dan realisasi kunjungan)

2) SPB (Surat permintaan barang)

3) Faktur

4) BTB (Bukti tanda barang)

5) BKT (Bukti kas terima) 


\section{Sistem dan Prosedur Penjualan Kredit}

1. Penjualan Kredit

Sistem penjualan kredit di Sosro merupakan penjualan dimana pembayarannya dilakukan setelah barang diterima pembeli dan pembayarannya menggunakan kartu kredit. Jumlah dan jatuh tempo pembayaranya disepakati oleh kedua belah pihak.

2. Prosedur Penjualan Kredit

Prosedur yang membentuk sistem dalam sistem penjualan kredit adalah sebagai berikut :

a. Prosedur order penjualan

Dalam prosedur ini, penjualan ini dilakukan oleh bagian penjualan atau salesman. Salesman ini bertanggung jawab menawarkan produk dan mendistribusikannya ke konsumen. Selanjutnya salesman mengisi faktur. Dalam penjualan kredit, costumer dapat mengurus sendiri pengajuan kredit, tetapi dapat juga diurus oleh perusahaan. Faktur ini ditanda tangani oleh salesman dan pelanggan. Faktur ini dibuat 4 rangkap, dimana lembar ke 1 dibagian ADM piutang, lembarke 2 diberikan kepada pelanggan lembar ke 3 diberikan kebagian ADM penjualan dan lembar ke 4 akan di arsip oleh salesman.

b. Prosedur penagihan

Dalam prsedur ini, penagihan pelunasan dilakukan oleh salesman yang bersangkutan. Pembayaran biasanya dilakukan melalui transfer kerekening perusahaan

c. Prosedur pencatatan

Dalam prosedur ini, pencatatan harian dilakukan oleh bagian kasir. Kasir menerimauang dari salesman disertakan dengan bukti penerimaan kas, lalu kasir akan memeriksa antara jumlah uang setor dengan jumlah uang ditulis dibukti penerimaan kas tersebut. Jika jumlah nya sama maka kasir akan menandatangani bukti penerimaan kas. Bukti tersebut erdiri dari dua rangkap, lembar ke satu di arsip oleh kasir dan lembarke 2 di arsip oleh salesman. Selanjutnya uang setoran salesman tersebut aan disetor kembali ke security call.dan dokumen yang digunakan cukup sederhana dengan menggunakan KBT (Kas besar terima) yang telah diferifikasi oleh staff administrasi.

\section{Sistem Pengendalian Internal atas Penjualan yang Diterapkan di PT. Sinar Sosro}

Pengendalian internal yang dilakukan perusahaan berupa pengawasan begitu juga yang dilakukan oleh PT.Sinar Sosro. Pengawasan yang dilakukan berdasarkan tujuan dibagi menjadi dua yaitu :

1. Pengawasan Akuntansi

Pengawasan akuntansi yang dilakukan PT.Sinar Sosro dengan menggunakan mesin kasir (cash register). Mesin kasir merupakan suatu peralatan mekanik maupun elektronik untuk menghitung jumlah transaksi penjualan yang biasanya terintegrasi secara model laci (cash drawer) untuk menyimpan sejumlah mata uang. Mesin kasir juga mengeluarkan hasil cetak (print) struk penjualan untuk pelanggan. Pergerakan penjualan produk akan selalu dimonitor oleh kepala gudang.

2. Pengawasan Manajemen

PT.Sinar Sosro memiliki aturan untuk semua karyawannya yang harus 
dipatuhi dan dilaksanakan. Aturan ini dibuat oleh manajemen perusahaan agar dapat hasil yang maksimal (keuntungan) yang dapat mencapai visi dan misi yang telah ada diperusahaan tersebut. Misalnya pembagian tugas, karyawan harus datang tepat waktu, dan karyawan bekerja dengan teliti.

Pengawasan berdasarkan sebuah lingkungan dibagi menjadi dua yaitu:

a. Pengawasan Umum

Pengawasan umum adalah pengawasan yang berlaku secara keseluruhan, baik tingkat bawah sampai tingkat atasan. Misalnya penerapan kedisiplinan, pemberian kode pada dokumen, setiap transaksi melibatkan lebih dari satu karyawan pada bagian terpisah agar terhindar dari penggelapan.

b. Pengawasan Aplikasi

Pengawasan yang diterapkan pada prosedur tertentu, misalnya pengawasan pada prosedur penjualan. Pengawasan ini meliputi pengawasan dari input penjualan, proses, keluaran, penyimpanan, dan basis datanya.

Pengawasan berdasarkan kegiatan dibagi menjadi tiga yaitu:

1) Pengawasan Prefentiv

Pengawasan yang dilakukan untuk mencegah terjadinya kesalahan dan penyelewengan. Misalnya menggunakan password dalam software akuntansi, dan memasang cctv pada setiap ruangan.

2) Pengawasan Detektif

Jika sudah menemukan adanya kesalahan dan penyelewengan maka pengawasan detektif perlu dilakukan. Contoh jika ditemukan kejanggalan pada laporan keuangan segera melakukan pengawasan detektif.

3) Pengawasan Korektif

Pengawasan yang dilakukan untuk mengoreksi kesalahan. Contoh mengadakan pengawasan pada dokumen dokumen penting, seperti laporan setoran penjualan, dan laporan penerimaan barang.

Tabel

Data Penjualan 2015 sampai 2018 (PT. Sinar Sosro)

\begin{tabular}{|c|c|c|c|c|}
\hline \multirow{2}{*}{ Bulan } & \multicolumn{4}{|c|}{ Tahun } \\
\cline { 2 - 5 } & $\mathbf{2 0 1 5}$ & $\mathbf{2 0 1 6}$ & $\mathbf{2 0 1 7}$ & $\mathbf{2 0 1 8}$ \\
\hline Januari & 65.000 & 73.000 & 96.200 & 105.400 \\
\hline Februari & 63.100 & 72.400 & 97.700 & 105.400 \\
\hline Maret & 72.500 & 84.400 & 99.100 & 107.900 \\
\hline April & 75.600 & 84.400 & 100.000 & 108.700 \\
\hline Mei & 76.900 & 85.600 & 100.500 & 110.300 \\
\hline Juni & 78.200 & 86.100 & 104.500 & 111.000 \\
\hline Juli & 80.600 & 87.300 & 105.000 & 111.800 \\
\hline Agustus & 82.900 & 88.900 & 111.000 & 112.100 \\
\hline September & 85.100 & 91.200 & 111.500 & 112.800 \\
\hline Oktober & 87.300 & 93.100 & 111.500 & 113.100 \\
\hline November & 88.900 & 94.400 & 112.100 & 113.700 \\
\hline Desember & 89.900 & 95.100 & 112.800 & 114.600 \\
\hline Jumlah & Rp. 9.46000 & Rp. 10.35900 & Rp. 12.61900 & Rp. 13.26800 \\
\hline
\end{tabular}

Dilihat dari data perbulan antara tahun 2015 sampai 2018 di PT. SINAR SOSRO BOGOR sudah mengalami peningkatan penjualan, walaupun peningkatannya tidak signifikan, dan jumlah transaksi di tahun 2015 sampai 2018 sudah dapat dilihat adanya efektifitas penerimaan kas atas penjualan, maka dengan kenaikan penjualan tersebut otomatis akan meningkatkan jumlah kas yang diterima.

\begin{tabular}{|c|c|c|c|}
\hline TAHUN & JUMLAH & TUNAI & KREDIT \\
\hline 2015 & Rp. 946.000 & Rp. 526.000 & Rp. 420.000 \\
\hline 2016 & Rp. 1.035900 & Rp. 600.000 & Rp. 435.900 \\
\hline 2017 & Rp. 1.261900 & Rp. 701.000 & Rp. 560.900 \\
\hline 2018 & Rp. 1.326800 & Rp. 806.800 & Rp. 520.000 \\
\hline JUMLAH & Rp. 4.570 .600 & Rp. 7.508 .326 & Rp. 1.936 .800 \\
\hline
\end{tabular}

Penjualan tahun 2015 sampai 2016 kenaikan disebabkan adanya varian rasa baru dan peminatnya banyak, dan ditahun 2017 kenaikan disebabkan adanya prodak baru dan ada diskon beli 1 gratis 1 dan dibantu oleh pembentukan divisi marketing oleh sebab itu kenaikan harga menjadi lebih 
baik, di tahun 2018 juga kenaikan disebabkan pihak PT. Sinar Sosro bekerjasama dengan tempat rekreasi.

\section{KESIMPULAN}

Dari hasil pembahasan mengenai Peranan Sistem Pengendalian Internal Atas Penjualan Untuk Meningkatkan Efektifitas Penerimaan Kas yang dilakukan oleh PT. Sinar Sosro sebagai berikut :

1. Dalam penerapan sistem pengendalian telah menerapkan beberapa pengawasan, seperti; pengawasan akuntansi dan pengawasan manajemen.

2. Penjualan dilaksanakan dengan SOP /prosedur yang sudah ditetapkan dan secara otomatis pengendalian internal telah berjalan dengan efektif atas transaksi penjualan (secara tunai).

\section{DAFTAR PUSTAKA}

Alvin, A. Arens, 2007, Auditing dan Pelayanan Verifikasi Jilid 1: Pendekatan Terpadu, dialih bahasakan oleh Tim Dejacarta, Edisi 9, Indeks : Jakarta.

Arens, A.A. dan Loeblecke, J.K. 2001. Auditing Pendekatan Terpadu. Salemba Empat: Jakarta.

Arief Sugiono. 2009. Manajemen Keuangan Untuk Praktisi Keuangan. PT Grasindo. Jakarta.

Arifin, Johar. Analisis Laporan Keuangan Berbasis Komputer. Jakarta: PT. Elex Media Komputindo.

Bastian Bustami. Nurela. 2010. Akuntansi Biaya. Edisi 2. PT Mitra Wacana Media. Jakarta.

Drs. Danang Sunyoto, S.H., S.E., M.M. 2014. Auditing Pemeriksaan Akuntansi. Yogyakarta: CAPS.
Golrida Karyawati. 2011. Akuntansi Keuangan Lanjutan. Edisi IFRS Erlangga. Jakarta.

Hery. 2013. Akuntansi Dasar 1 \& 2. PT Grasindo. Jakarta.

Irham Fahmi. 2013. Manajemen Risiko. CV. Alfabeta. Bandung.

Irna Febria. 2015. Pengaruh perputaran persediaan terhadap tingkat likuiditas pada PT. Smart Tbk. Bogor: Universitas Pakuan.

Kasmir. 2011. Analisis Laporan Keuangan. Rajawali Pers. Jakarta. Lili M Sadeli. 2008. Dasar-Dasar Akuntansi. Bumi Aksara. Jakarta.

Mulyadi. 2001. Sistem Informasi Akuntansi. Edisi 3. Jakarta: Salemba Empat.

Mulyadi. 2008. Sistem Akuntansi. Cetakan Ketiga. Edisis Ketiga, Salemba. Empat. Jakarta.

Novitasari, Esterina. 2010. SPI Penerimaan Kas pada PD BPR BKK Karangmalang Cabang Sragen. Semarang: Universitas Sebelas Maret.

Rapina Putri Hariri. 2011. Peranan sistem pengendalian internal dalam meningkatkan efektivitas dan efisiensi kegiatan operasional pada siklus persediaan dan pergudangan. Bogor: Universitas Juanda.

Ross, Stephen A. Westerfield, Randolph W. Jordan, Bradford D. 2009. Pengantar Keuangan Perusahaan. Edisi 8, Salemba Empat. Jakarta. Sentot Imam Wahjono. 2010. Bisnis Modern. Edisi Pertama, Graha Ilmu. Yogyakarta.

Sulistrayaningsih. 2013. Analisis SPI Penerimaan dan Pengeluaran Kas Terhadap Kecurangan Kas Pada 
BPR Tanjung Pinang. Tanjung Pinang:Universitas Maritim Raja Ali Haji.

Tim Penyusun Pedoman Penulis Seminar Proposal dan Skripsi S1. 2016. Pedoman Penulisan Seminar Proposal Dan Skripsi S1 Fakultas Ekonomi. Universitas Ibnu Khaldun. Bogor.

V. Wiratna Sujarweni. 2015. Sistem Akuntansi. Cetakan pertama, Bantul, Yogyakarta: Pustaka Baru Press. 